Annals of Warsaw University of Life Sciences - SGGW

Land Reclamation No 40, 2008: 97-105

(Ann. Warsaw Univ. of Life Sci. - SGGW, Land Reclam. 40, 2008)

\title{
The use of dilatometer test for the determination of undrained shear strength in organic soils
}

SIMON RABARIJOELY

Department of Geotechnical Engineering, Warsaw University of Life Sciences

\begin{abstract}
The use of dilatometer test for the determination of undrained shear strength in organic soils. In engineering practice the empirical correlations or charts are often use to determine soil properties for design calculations. The DMT tests results are analysed on the basis of the empirical formulas proposed by Marchetti (1980). In this paper the new chart to determine the $\tau_{\mathrm{fu}}$ of organic mud was proposed. The chart presents the relationships between dilatometer readings $\left(\mathrm{p}_{\mathrm{o}}-\mathrm{u}_{\mathrm{o}}\right),\left(\mathrm{p}_{1}-\mathrm{u}_{\mathrm{o}}\right), \sigma^{\prime}{ }_{\mathrm{vo}}$ and $\tau_{\mathrm{fu}}$. The chart will be helpful in geotechnical design of embankments constructed on organic subsoil.
\end{abstract}

Key words: dilatometer test, organic soils, undrained shear strength.

\section{INTRODUCTION}

Safe and economic design of the structure on organic subsoil demands the exact recognition of the subsoil properties among them undrained shear strength $\tau_{\mathrm{fu}}$ (Hartlen and Wolski 1996). In Poland there are many areas covered by very soft deposits, including organic soils characterised with low undrained shear strength and high compressibility. Recently for recognised of the geotechnical condition in organic soils the application of DMT tests are recommended (Lechowicz and Rabarijoely 1996, Młynarek et al. 2006).
Advantage of the DMT test (Marchetti 1980) is the quick and not complicated measurements. Based on the DMT tests results the subsoil profiles and many soil parameters (deformation modulus $\mathrm{M}_{\mathrm{DMT}}$ and shear strength $\tau_{\mathrm{fu}}$ ), can be determined. The interpretation of organic soil parameters is based on the empirical formulae. In this paper the tests results for organic soils in Nielisz dam foundation are presented. After analysis of the DMT parameters test results new chart for the determination of undrained shear strength for organic muds is proposed.

\section{INTERPRETATION OF DILATOMETER TEST AND TEST RESULTS}

The DMT test consists in measurement at given depths during penetration of subsoil the gas pressure on the membrane installed in the DMT blade. Most often two readings $\mathrm{A}$ and $\mathrm{B}$ are measured. The A reading is equivalent to value of the gas pressure to dislocate of the membrane centre for the contact with surrounding soil (usually 0.05 $\mathrm{mm})$. The second $\mathrm{B}$ reading shows the value of the gas pressure obtained at the additional inclination of the centre of the membrane toward of the soil about 
$1.05 \mathrm{~mm}$ (together $1.1 \mathrm{~mm}$ ). Recently, more and more often after the realization of $\mathrm{A}$ and $\mathrm{B}$ readings passed is the third $\mathrm{C}$ reading - the gas pressure after the return of the membrane to the initial positions (Fig. 1). Values of A, B and C readings are corrected for the influence of the membrane resistance, what lets to the determination of the $\mathrm{p}_{\mathrm{o}}, \mathrm{p}_{1}$ and $\mathrm{p}_{2}$ pressures (Fig. 1). The detail procedure of DMT tests is presented in many papers (Lutenegger and Kabir 1988, Totani et al. 1998, Marchetti and Crapps 1981, Schmertmann 1986, Briaud and Miran 1992, Marchetti 1999).

The $p_{0}, p_{1}$ and $p_{2}$ pressures together with the calculated effective vertical stress $\sigma_{\text {vo }}^{\prime}$ and water pore pressure $u_{o}$ of in situ conditions serve to the obtaining of following indexes of the dilatometer (Marchetti 1980, Lutenegger and Kabir 1988):

- Material index $I_{D}$

$$
I_{D}=f\left(A, B, u_{o}\right)=\frac{p_{1}-p_{o}}{p_{o}-u_{o}}
$$

- Horizontal stress index $K_{D}$
$K_{D}=f\left(A, u_{o}, \sigma_{v o}^{\prime}, B\right)=\frac{p_{o}-u_{o}}{\sigma_{v o}^{\prime}}$

- Dilatometer modulus $\mathrm{E}_{\mathrm{D}}$

$E_{D}=f(A, B)=34.7\left(p_{1}-p_{o}\right)$

- Pore pressure index $U_{D}$

$U_{D}=f\left(A, C, u_{o}, B\right)=\frac{p_{2}-u_{o}}{p_{o}-u_{o}}$

\section{THE DMT TEST RESULTS}

\section{AT NIELISZ SITE}

The comprehensive field and laboratory tests were performed by the Department of Geotechnical Engineering SGGW at the Nielisz site (the river Wieprz valley) (Lechowicz 1992, Lechowicz and Rabarijoely 1996). The organic subsoils in Nieliszdam foundation are organic mud (Tab. 1). Thickness of the organic mud varies from 3 to $5 \mathrm{~m}$. This soil is lightly preconsolidated with overconsolidation ratio $\mathrm{OCR}=2-3$. Due to very high compressibility of organic subsoils and its low undrained shear strength values the Nielisz dam was constructed in two

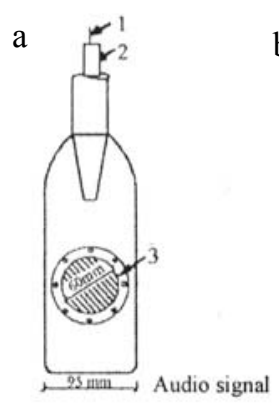

Reading b

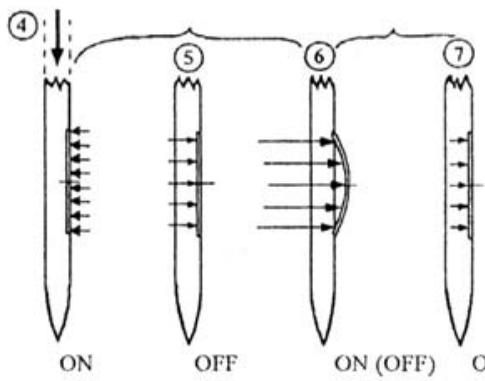

B

FIGURE 1. Marchetti dilatometer: a - flat blade $(1$ - electric wire, 2 - pneumatic tubing, 3 - steel membrane), $b$ - test stages ( 4 - pushing, 5 - contact pressure $p_{o}, 6$ - expansion pressure $p_{1}, 7$ - pressure $\mathrm{p}_{2}$ ) 
TABLE 1. Index properties of organic mud at the Nielisz test site

\begin{tabular}{|c|c|c|c|c|c|c|}
\hline \multirow[b]{2}{*}{ Parameters } & \multirow{2}{*}{$\begin{array}{l}\text { Organic } \\
\text { content } \\
\mathrm{I}_{\text {om }}[\%]\end{array}$} & \multirow{2}{*}{$\begin{array}{c}\text { Content } \\
\mathrm{CaCO}_{3} \\
{[\%]}\end{array}$} & \multirow{2}{*}{$\begin{array}{c}\text { Water } \\
\text { content } \\
\mathrm{w}_{\mathrm{n}} \\
{[\%]}\end{array}$} & \multirow{2}{*}{$\begin{array}{c}\text { Liquid limit } \\
\mathrm{w}_{\mathrm{L}} \\
{[\%]}\end{array}$} & \multicolumn{2}{|c|}{ Density } \\
\hline & & & & & $\begin{array}{c}\text { Unit } \\
\rho\left[\mathrm{t} / \mathrm{m}^{3}\right]\end{array}$ & $\begin{array}{l}\text { Specific } \\
\rho_{\mathrm{s}}\left[\mathrm{t} / \mathrm{m}^{3}\right]\end{array}$ \\
\hline \multirow{2}{*}{ Values } & $20-30$ & - & $120-150$ & $130-150$ & $1.25-1.30$ & $2.25-2.3$ \\
\hline & $10-20$ & - & $105-120$ & $110-130$ & $1.30-1.45$ & $2.30-2.40$ \\
\hline
\end{tabular}

stages with surcharge embankment (Lechowicz and Rabarijoely 1997).

The DMT tests results are presented in Figure 2 for virgin subsoil and loaded subsoil by Nielisz dam. The Figure 2 shows the profiles of calculated values as follows: the material index of $\mathrm{I}_{\mathrm{D}}$, the horizontal stress index $\mathrm{K}_{\mathrm{D}}$, the dilatometer modulus $\mathrm{E}_{\mathrm{D}}$ and the pore pressure index $\mathrm{U}_{\mathrm{D}}$.

\section{THE DETERMINATION}

OF UNDRAINED SHEAR

STRENGTH - PROPOSED CHART

Recently, many studies have been performed and new correlations improved original ones proposed by Marchetti were introduced in geotechnical practice; the most of them regards only mineral soils (Lutenegger 1988, Campanella and Robertson 1991, Leroueil and Jamiolkowski 1991, Finno 1993). According to Marchetti proposal the undrained shear strength of mineral soils can be obtained using following formulae:

$\frac{\tau_{\mathrm{fu}}}{\sigma_{\mathrm{v}^{\prime} \mathrm{o}}}=0.225\left(0.5 \cdot \mathrm{K}_{\mathrm{D}}\right)^{1.25}$

Hitherto exist results, both laboratory investigations (triaxial test), as and field (field vane test and dilatometer test) (Fig. 3) they show, that the profile of undrained shear strength $\tau_{\mathrm{fu}}$ of organic mud has non-linear character. Proposed

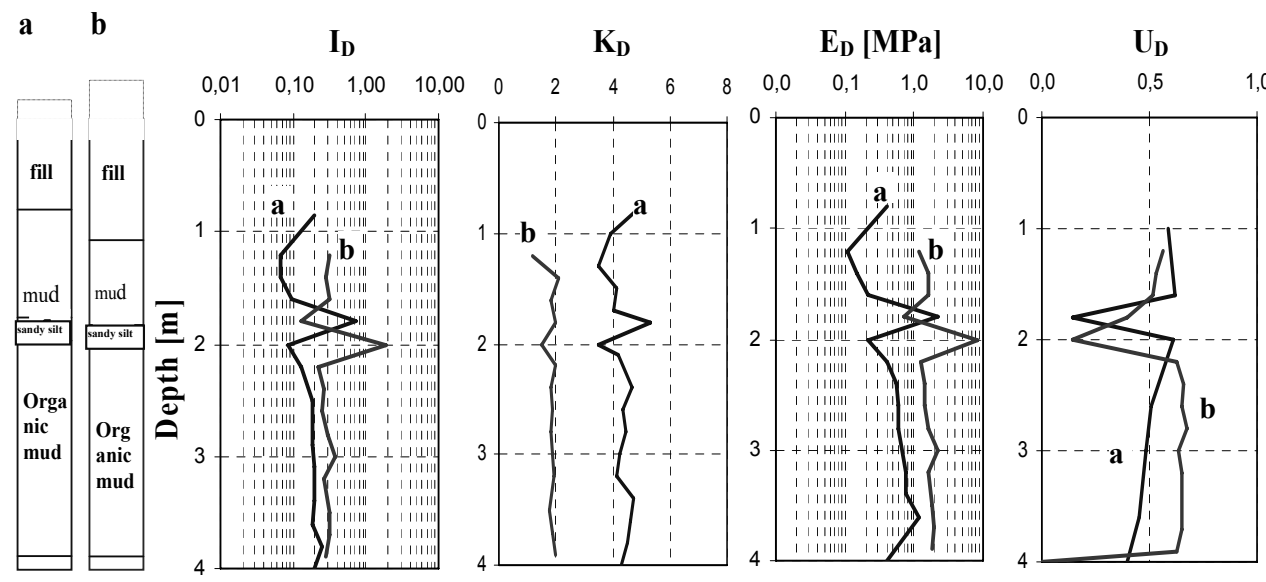

FIGURE 2. Indexes parameters of $\mathrm{I}_{\mathrm{D}}, \mathrm{K}_{\mathrm{D}}, \mathrm{E}_{\mathrm{D}}$ and $\mathrm{U}_{\mathrm{D}}$ profiles from dilatometer the test at the Nielisz site: $\mathrm{a}$ - virgin soft subsoil; $\mathrm{b}$ - under loading 
by Marchetti correlation (eq. 5) does not describe $\tau_{\mathrm{fu}}$ for organic mud got from subsoil under Nielisz dam. With dilatometer test (DMT) it results, that to evaluate the $\tau_{f u}$ of organic mud from Nielisz site for help three factors such how: $\left(\mathrm{p}_{\mathrm{o}}-\mathrm{u}_{\mathrm{o}}\right),\left(\mathrm{p}_{1}-\mathrm{u}_{\mathrm{o}}\right), \sigma_{\text {vo }}$ (eq. 6 ).

For organic soils new equation was proposed (Rabarijoely 2000) as follow:

$$
\tau_{f u}=\alpha_{o} \cdot \sigma_{v}{ }^{\alpha_{1}} \cdot\left(p_{o}-u_{o}\right)^{\alpha_{2}} \cdot\left(p_{1}-u_{o}\right)^{\alpha_{3}}
$$

Empirical coefficients to power form of proposed dependence one can so mark on the soil the porosity indexes e from the dependence (eq. 7):

$$
\alpha_{i}=C_{i} \cdot e+D_{i}
$$

where: $C_{i}, D_{i}-$ coefficients given in the Table 2

- the organic mud $\left(\mathrm{I}_{\mathrm{om}}=20 \%\right)$ :

$\alpha_{0}=0,686, \alpha_{1}=0.075, \alpha_{2}=0.109$,

$\alpha_{3}=0.587$

- the organic mud $\left(\mathrm{I}_{\mathrm{om}}=10 \%\right)$ :

$\alpha_{0}=1.124, \alpha_{1}=0.134, \alpha_{2}=0.096$, $\alpha_{3}=0.441$

Above mentioned equation was applied for determination of $\tau_{\mathrm{fu}}$ profiles of in foundation of Nielisz dam (Fig. 3).

Obtained results to analyse for each kinds of organic muds the coefficient of the determination $\mathrm{R}^{2}>95 \%$ what testifies the strong account among the dependent variable $\tau_{\mathrm{fu}}$ and with independent variables $\sigma_{\text {vo }}^{\prime}, p_{0}-u_{0}, p_{1}-u_{0}$ (Rabarijoely
2000). From the comparison of maximum and average square relative deviations of the appointed undrained shear strength, it results that in the most of chances lower of their value one received for power form.

New chart consists with two parts. The bottom part of chart represents the value of undrained shear strength $\tau_{\mathrm{fu}}$ $(\mathrm{kPa})$ in dependence for $\sigma^{\prime}{ }_{\mathrm{vo}}=10 \mathrm{kPa}$, $\mathrm{p}_{0}-\mathrm{u}_{\mathrm{o}}(\mathrm{kPa})$ and $\mathrm{p}_{1}-\mathrm{u}_{0}(\mathrm{kPa})$. It meanwhile the upper part of chart was used for determination of $\tau_{\mathrm{fu}}$ value for any $\sigma^{\prime}{ }_{v o}$ in data profiles (Fig. 4 for organic mud, $\mathrm{I}_{\mathrm{om}} 10 \%, \mathrm{e}_{0}=2.5$ and Fig. 5 for organic mud, Iom $20 \%, e_{0}=3.15$ ).

The undrained shear strength $\tau_{\mathrm{fu} 1}$ appointed (Figs. $4 b, 5 b$ ) as functions of $\mathrm{p}_{1}-\mathrm{u}_{\mathrm{o}}(\mathrm{kPa})$ and $\mathrm{p}_{\mathrm{o}}-\mathrm{u}_{\mathrm{o}}(\mathrm{kPa})$. Instead on the Figure the outline $4 \mathrm{a}$ these lines top -down" is presented by exact values $\tau_{\text {ful }}(\mathrm{kPa})$ read from the Figure $b$ from which depend values $\sigma_{\text {vo }}^{\prime}(\mathrm{kPa})$ and $\tau_{\mathrm{fu}}$ $(\mathrm{kPa})$.

The undrained shear strength of organic mud $\left(\mathrm{I}_{\mathrm{om}}=10 \div 20 \%, \mathrm{e}_{0}=2.5\right.$ $\div 3.15$ ) can be obtained using proposed chart presented in Figures 4 and 5 according to the manner:

In order to determine undrained shear strength $\tau_{\mathrm{fu}}(\mathrm{kPa})$ one marks on the suitable chart following points:

- on the Figure $5 b$ axled of abscissae one qualifies sharp $A$ answering of the value $\mathrm{p}_{\mathrm{o}}-\mathrm{u}_{\mathrm{o}}(\mathrm{kPa})$,

TABLE 2. Coefficient values $\alpha_{\mathrm{o}}, \alpha_{1}, \alpha_{2}$ and $\alpha_{3}$ determined for organic mud from Nielisz

\begin{tabular}{|l|c|c|c|c|c|c|}
\hline \multirow{2}{*}{ Parameter } & \multirow{2}{*}{$\mathrm{e}$} & \multirow{2}{*}{$\mathrm{I}_{\mathrm{om}}$} & \multicolumn{4}{|c|}{ Value of empirical coefficients } \\
\cline { 4 - 7 } & & & $\alpha_{\mathrm{o}}$ & $\alpha_{1}$ & $\alpha_{2}$ & $\alpha_{3}$ \\
\hline \multirow{2}{*}{ value } & 2.4 & $10 \%$ & 1.124 & 0.134 & 0.096 & 0.441 \\
\cline { 4 - 7 } & 3.15 & $20 \%$ & 0.686 & 0.075 & 0.109 & 0.587 \\
\hline
\end{tabular}


a

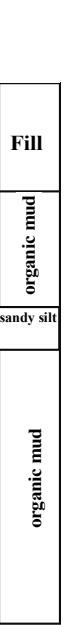

Undrained shear strength $\tau_{\mathrm{fu}}[\mathrm{kPa}]$

0

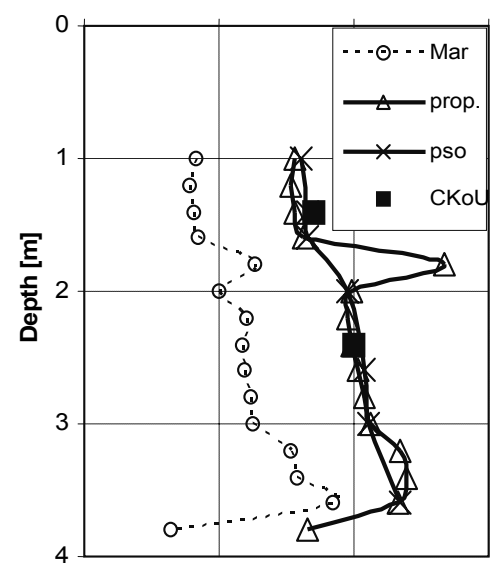

b

30

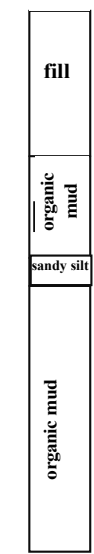

Undrained shear strength $\tau_{\mathrm{fu}}[\mathrm{kPa}]$

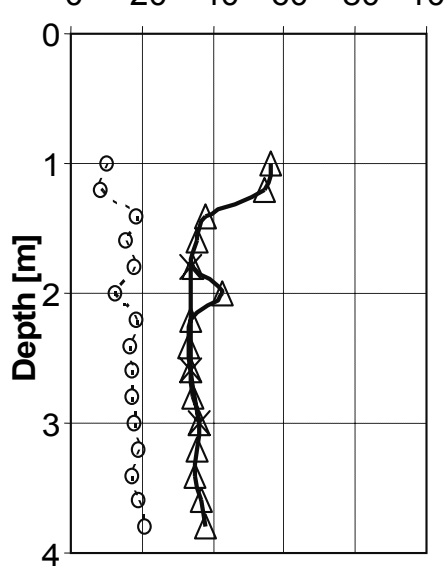

FIGURE 3. Profiles of undrained shear strength (a): in virgin soft subsoil - (b): under loading, in crosssection hm 4+50: dilatometer test: ———Marchetti (5), — — — proposed eq. (6), — X-PSO - field vane shear test, $\longrightarrow-C K_{0} U$ triaxial tests

- axled of ordinates one qualifies point $\mathrm{B}$ answering of the value $\mathrm{p}_{1}-\mathrm{u}_{\mathrm{o}}(\mathrm{kPa})$,

- straight taken from these points parallel to the coordinate axis will mark local cuts themselves point $\mathrm{C}$,

- curvilinear taken from the point C parallel to the line of the shear strength $\tau_{\mathrm{fu}}(\mathrm{kPa})$ it will mark on the upper horizontal scale - point $\mathrm{D}$,

- the sloping line taken from the point $\mathrm{D}$ on the Figure $4 \mathrm{~b}$ to the same value $\tau_{\mathrm{fu}}$ $(\mathrm{kPa})$ on the Figure 5a and will mark point $\mathrm{E}$,

- on the Figure 5a, axled of abscissae one qualifies point $\mathrm{F}$ answering of the value $\sigma^{\prime}{ }_{v o}$ for which value of the undrained shear strength $\tau_{\mathrm{fu}}(\mathrm{kPa})$ is a value to finding,

- point cuts himself straight of taken from the point $F$ parallel to the axis of the ordinate and curvilinear from the point $\mathrm{E}$ of the parallel to the line of the undrained shear strength $\tau_{\text {ful }}(\mathrm{kPa})$ marks point $\mathrm{G}$,
- straight taken from the point $G$ vertically upward will mark in the cut with the upper scale horizontal point $F$ whose the reading will qualify the undrained shear strength value $\tau_{\mathrm{fu}}(\mathrm{kPa})$.

\section{CONCLUSIONS}

Taking into account comprehensive investigation performed by the Department of Geotechnical Engineering SGGW at Nielisz site new chart for determination of undrained shear strength of organic mud was proposed. The new chart (Figs. 4 and 5) will let on the determination of the undrained shear strength $\tau_{f u}$ for organic mud (degree of decomposition $\left.\mathrm{I}_{\mathrm{om}}=10-20 \%\right)$ and lightly preconsolidated $(\mathrm{OCR}=2-3)$. To the use of this chart proper value of the effective vertical stresses $\sigma_{\text {vo }}^{\prime}$ and the hydrostatical pressure $u_{o}$ were necessary. Proposed chart is 

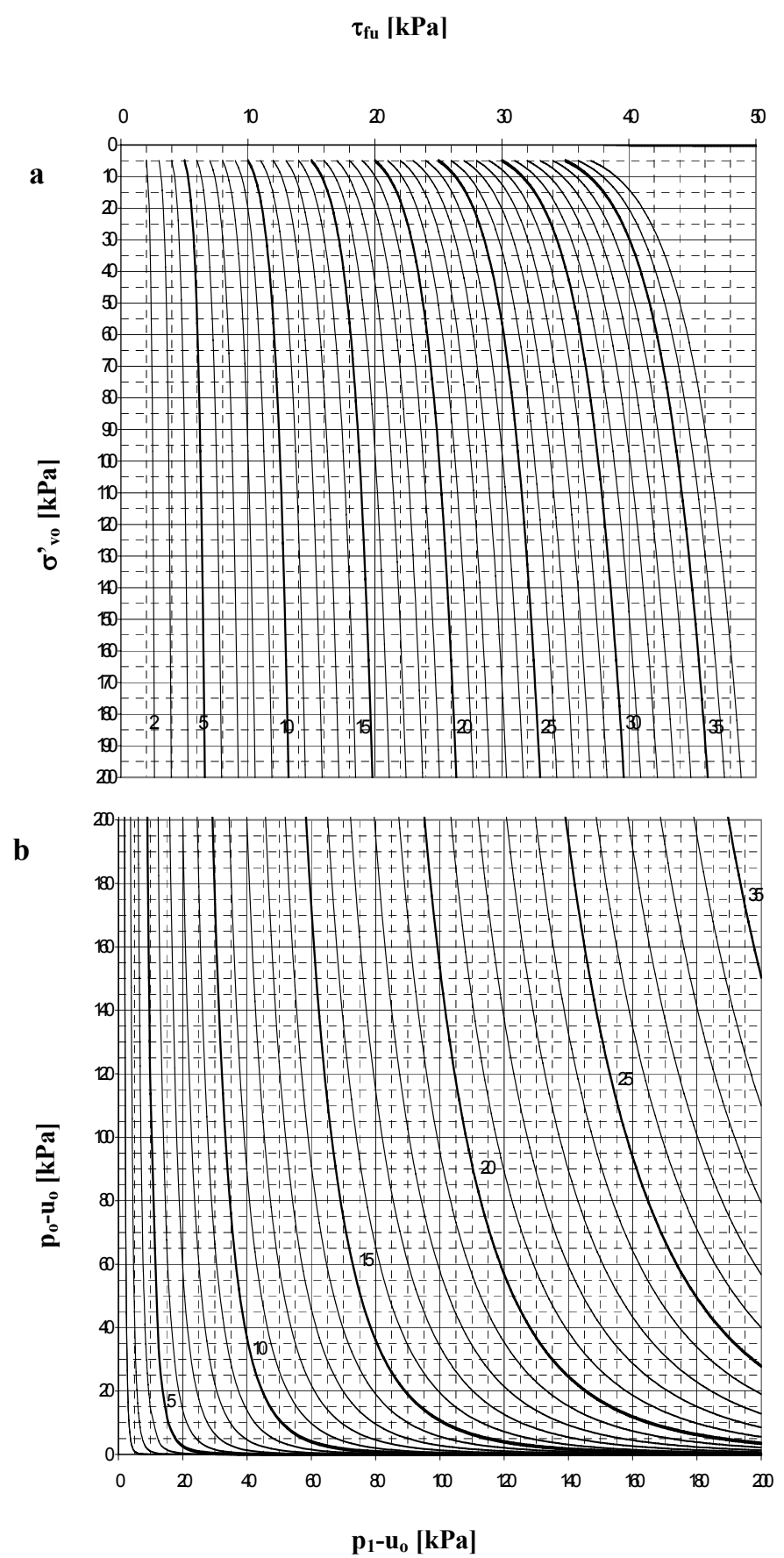

FIGURE 4. The chart for determination of the undrained shear strength $\tau_{\mathrm{fu}}$ for organic mud $\left(\mathrm{I}_{\mathrm{om}} 10 \%\right.$, $\left.\mathrm{e}_{0}=2.5\right)$ from dilatometer test (Rabarijoely 2000); part of $\tau_{\mathrm{fu}}$ dependent on: $\mathrm{a}-\left(\mathrm{p}_{\mathrm{o}}-\mathrm{u}_{\mathrm{o}}\right)$ and $\left(\mathrm{p}_{1}-\mathrm{u}_{\mathrm{o}}\right)$, $\mathrm{b}-\sigma^{\prime}{ }_{\text {vo }}$ 


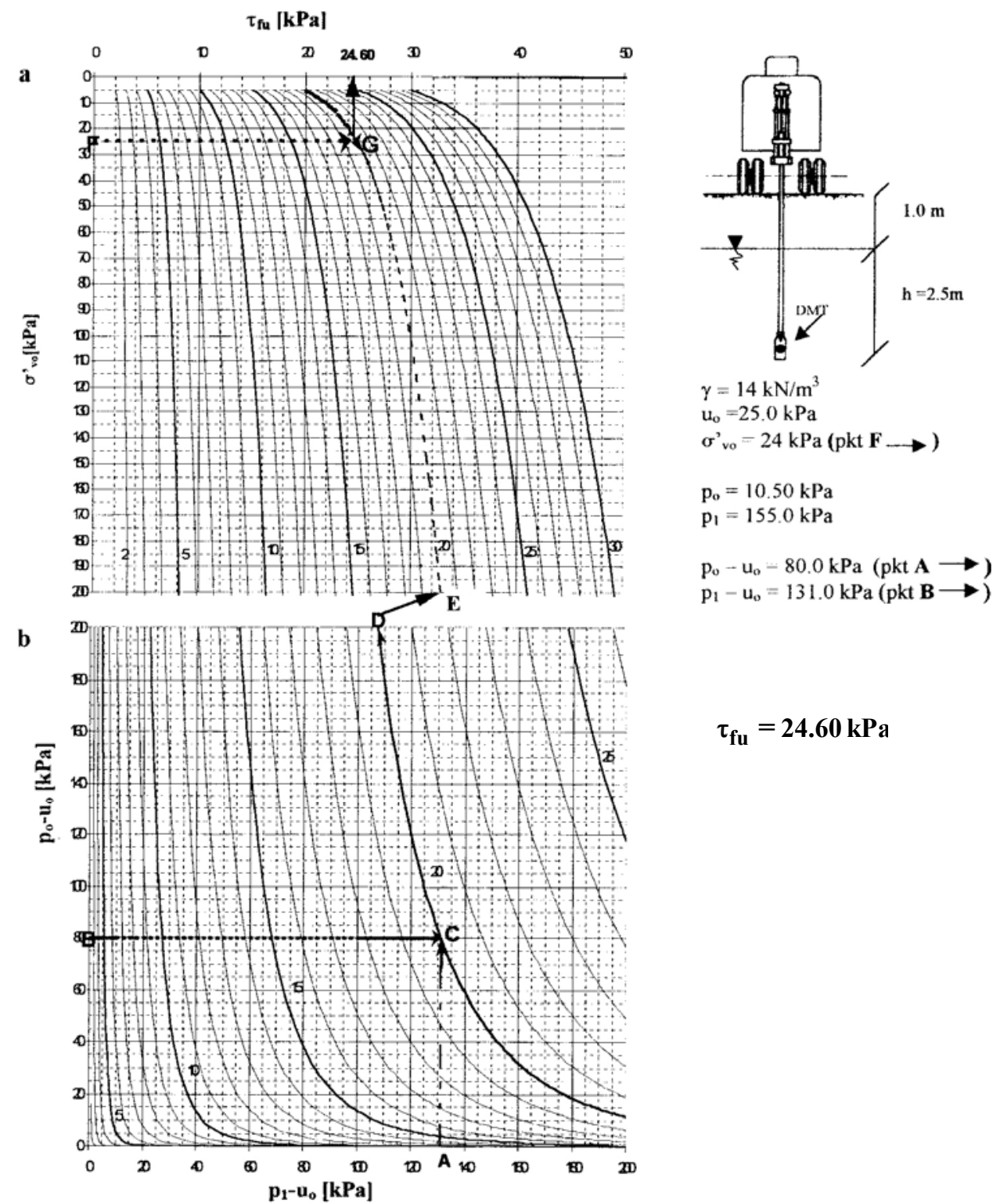

FIGURE 5. Manner of the utilization the chart to determine the undrained shear strength $\tau_{\mathrm{fu}}$ for organic mud $\left(\mathrm{I}_{\mathrm{om}} 20 \%, \mathrm{e}_{0}=3.15\right)$ from dilatometer test (Rabarijoely 2000); part of $\tau_{\mathrm{fu}}$ dependent on: $\mathrm{a}-\left(\mathrm{p}_{\mathrm{o}}\right.$ $-\mathrm{u}_{\mathrm{o})}$ and $\left(\mathrm{p}_{1}-\mathrm{u}_{\mathrm{o}}\right), \mathrm{b}-\sigma_{\mathrm{vo}}$ 
simple in use and helpful in geotechnical practise for determination of undrained shear strength from DMT tests.

\section{REFERENCES}

BRIAUD J., MIRAN J. 1992: The flat dilatometer test, TX, 77843-3136 USA for The Federal Higway Administration.

CAMPANELLA R.G., ROBERTSON P.K. 1991: Use and interpretation of a research dilatometer. Can. Geotech., J., 28: 113-126.

FINNO R.J. 1993: Analytical interpretation of dilatometer penetration through saturated cohesive soils. Géotechnique, 43 , No 2, 241-254.

HARTLEN J., WOLSKI W. 1996: Embankments on organic soils. Amsterdam, Elsevier.

LADD C.C., FOOTT R., ISHIHARA K., SCHLOSSER F., POULOS H.G. 1977: Stress-deformation and strength characteristics. Proc. 9th Int. Conf. on Soil Mech. and Foun. Eng., Tokyo, 2; 421-494.

LECHOWICZ Z. 1992: Ocena wZmocnienia gruntów organicznych obciazzonych nasypem. [An evaluation of the increase in the shear strength of organic soils under embankment loading]. Treatises and monographs. Wydawnictwo SGGW. [In Polish].

LECHOWICZ Z., RABARIJOELY S. 1996: Wykorzystanie badań in situ $\mathrm{W}$ ocenie wzmocnienia słabonośnego podłoża zapory budowanej etapowo [Use of in situ tests in evaluation of soft subsoil strengthening during staged construction]. Mat. na VII Konf. Techn. Kon. Zap., Rytro, 231-240. [In Polish.]

LECHOWICZ Z., RABARIJOELY S. 1997: Use of dilatometer test in evaluation of organic subsoil strengthening. Proc. of Conf. on Rec. Adv. In Soft Soil Eng., Vol. I. Kuching, Sarawak, Malaysia, 185-196.
LEROUEIL S., JAMIOLKOWSKI M. 1991: Exploration of soft soil and determination of design parameters. General Report, Int. Conf. on Geotech. Eng. for Costal Develop. Yokohama.

LUTENEGGER A.J. 1988: Current status of the Marchetti dilatometer test. Proc. Int. Sym. On Penetration Testing ISOPT-1, Orlando, 1: 137-155.

LUTENEGGER A.J., KABIR M.G. 1988: Dilatometer C-reading to help determine stratigraphy. Proc. Int. Sym. on Penetration Testing ISOPT-1, Orlando, 1: 549-553.

MARCHETTI S. 1980: In Situ Tests by Flat Dilatometer. J. Geotech. Eng. Div., ASCE, 106, GT3: 299-321.

MARCHETTI S., CRAPPS D.K. 1981: Flat dilatometer manual. Internal report of GPE.

MARCHETTI S. 1999: On the calibration of the DMT membrane. L'Aquila Univ., Unpublished report.

MŁYNAREK Z., GOGOLIK S MARCHETTI D. 2006: Suitability of the SDMT method to assess geotechnical parameters of post-flotation sediments. Proc. of the Second International Flat Dilatometer Conference, Washington: 148-153.

RABARIJOELY S. 2000: Wykorzystanie badań dylatometrycznych w wyznaczeniu parametrów gruntów organicznych obciążonych nasypem [The use of dilatometer test for evaluation of organic soil parameters]. Ph. D. Thesis. Warsaw Agricultural University. [In Polish].

SCHMERTMANN J.H. 1986: Suggested method for performing the flat dilatometer test. ASTM Geotechnical testing Journal Vol. 9, No 2, p. 93-101.

TOTANI G., CALABRESE M. MARCHETTI S., MONACO P. 1998: Use of in situ flat dilatometer (DMT) for soil characterization in the stability analysis of slopes. Proc. 14th Int. Conf. on Soil Mech. and Foun. Eng., Hamburg, 1, 607-610. 
Streszczenie: Wykorzystanie badań dylatometrycznych do określenia wytrzymatości na ścinanie gruntów organicznych. W praktyce inżynierskiej zalecane jest stosowanie nomogramu zarówno $\mathrm{w}$ terenie, jak i w biurze projektowym; zarówno do posadowienia bezpośredniego, jak i pośredniego budowli inżynierskich. W nomogramie Marchettiego (1980) nie można bezpośrednio określić wytrzymałości gruntów na ścinanie w warunkach bez odpływu $\left(\tau_{\mathrm{fu}}\right)$ za pomocą wskaźnika $\mathrm{K}_{\mathrm{D}}$. Możliwe jest to jedynie za pomocą wzoru, ale wówczas konieczna jest znajomość współczynnika S, który jest istotnie związany z poszczególnymi warstwami gruntu (rodzaj gruntu). Do zależności potegowej trzyczynnikowej przy obliczaniu wytrzymałości na ścinanie w warunkach bez odpły- wu $\tau_{\text {fu }}$ uwzględniona została historia naprężenia (grunt nieobciążony i podobciążony). Do obliczenia zależności tej wykorzystuje się bezpośrednie pomiary odczyty dylatometryczne, co przyspiesza wykonanie obliczeń.

MS. received 8 November 2008

\section{Author's address:}

Simon Rabarijoely

Katedra Geoinżynierii

Wydział Inżynierii i Kształtowania Środowiska SGGW

02-776 Warszawa, ul. Nowoursynowska 159

Poland 